\title{
Inflation, Unemployment and the NAIRU in Pakistan (1975-2009)
}

\author{
Khalid Zaman \\ Assistant Professor, Department of Management Sciences \\ COMSATS Institute of Information Technology, Abbottabad, Pakistan \\ Tel: 92-334-898-2744; Fax: 92-992-383-441Ｅ-mail: khalidzaman@ciit.net.pk \\ Muhammad Mushtaq Khan \\ Head of Department (HOD), Management Sciences \\ COMSATS Institute of Information Technology, Abbottabad, Pakistan \\ Tel: 92-992-383-591-6; Fax: 92-992-383-441Ｅ-mail: khanmm@ciit.net.pk \\ Mehboob Ahmad \\ Professor of Management Sciences, FUIEMS, Foundation University \\ New Lalazar, Rawalpindi Cantt, Pakistan \\ Tel: 92-333-520-2377; Fax: 92-992-383-441Ｅ-mail: mmehboobahmad@gmail.com \\ Waseem Ikram \\ Assistant Professor, Management Sciences \\ COMSATS Institute of Information Technology, Abbottabad, Pakistan \\ Tel: 92-321-980-1301; Fax: 92-992-383-441Ｅ-mail: drwaseem@ciit.net.pk
}

\begin{abstract}
In a developing country like Pakistan, Phillips Curve approach is employed on a data set of 35 years starting from 1975-2009. Phillips Curve helps in examining the relationship between inflation and unemployment. There is a non-proportional negative relationship between inflation and unemployment (if unemployment is reduced than there is a rising price level in the economy). Non-parametric estimates of the NAIRU are calculated. In this study, results are in the range of $3.21-9.01$ percent. There is a long-run and casual relationship between inflation and unemployment over the above mentioned period in Pakistan. There is a transitory relationship (shocks) in the short-run, while there is a permanent relationship (shocks) in the long-run. By looking at the relationship established, one can forecast for next 10 years, that there will be an opposite relationship between both variables. This paper documents an empirical evidence for the existence of the Phillips curve in Pakistan i.e., inflation has decreased unemployment.
\end{abstract}

Keywords: Phillips curve, NAIRU, Granger causality, Impulse response function, Pakistan

Jel Classification Code: C22, E31, E50

\section{Introduction}

Over the last five decades, the subject of price/wage inflation and unemployment has been a major concern for economists and common economic agents. This approach started in 1958, when a British Economist A. W. Phillips wrote an article on "The Relationship between Unemployment and the Rate of Change of Money Wage Rates in the United Kingdom" by using a data set from 1862 to 1957 . This empirical study was formed by a reasonably smooth curve which is known as "Phillips Curve". Phillips curve shows a trade-off between rate of inflation and unemployment. Phillips Curve interprets that if unemployment is to be reduced than we have to accept the rising price level in the economy. Various theories have been put forward to explain continuing inflation all over the world. In Pakistan, the subject of inflation has been the central issue in most of macroeconomics studies. Various factors are considered in the literature as strong forces for determining price inflation. These factors are monetary expansion, stagnation of output, increasing import prices, increasing wage rates and sticky expectations etc.

\subsection{Research Hypothesis}

It has been observed that Inflation and unemployment have both direct and indirect relationships. Our hypothesis is to examine the existence of Phillips curve by considering, whether there is a direct or indirect relationship between inflation and unemployment in the context of Pakistan.

\subsection{Research Objectives}

The objective of this paper is to examine the existence of Phillips Curve in Pakistan, by using a time series data from 1975-2009. The more specific objectives are:

i. To estimate a short-run trade-off between inflation and unemployment, this is implied by the Phillips Curve and the NAIRU.

ii. To estimate a long-run relationship between inflation and unemployment over the last 35 years.

iii. To estimate changes in the unemployment rate, this is Granger cause changes in inflation. 
iv. To estimate permanent supply shocks, this drives both inflation and unemployment in the long-run. Whereas, in the short run the usual tradeoff is induced due to demand shocks.

This paper is organized in five sections. Section 2 presented a literature review. Section 3 focuses on inflation, unemployment, NAIRU and unemployment gap in Pakistan. Section 4 provides data source and methodological framework. The empirical results are presented in Section 5, while the final section concludes the study.

\section{Literature Review}

Paul Samuelson and Robert Solow were among the first researchers, who supported the Phillips hypothesis. Samuelson and Solow (1970) examined the relationship between the inflation and unemployment rate in the United States. An inverse relationship was established between inflation and unemployment. In another study conducted by Solow (1970) and Gordon (1971), results reveal the existence of a negative trade-off relationship between unemployment and inflation using U.S. macroeconomic data. These empirical findings have been known as the "Solow-Gordon affirmation" of the Phillips curve.

Although William Phillips based his hypothesis on a strong theoretical foundation, the debate on whether the Phillips curve really exists or does not exist dates back to the 1960s. Islam et al. (2003: 107) has noted that Phillips Curve is open to debates since its inception. Friedman (1968) and Phelps (1967) openly criticized the hypothesis and mentioned that there is no trade-off relationship between unemployment and inflation. Furthermore, Lucas (1976) strongly opposed the proposition of the existence of the Phillips curve. He argued that there could have been a trade-off relationship between unemployment and inflation, subject to the assumption that the policy makers have not created an artificial situation, where high-inflation is pared with low unemployment. Otherwise, the workers would foresee the high inflation in the future and would demand wage increase from their employers. In this case, there could be coexistence of high unemployment and high inflation rate which is known as the "Lucas critique".

In the 1970s, economists began to loose interest in doing research on the Phillips curve. As Debelle and Vickery (1998:384) commented, "The Phillips curve fell into a period of neglect in academic circles during the 1980s, however it remained an important tool for policy makers". 1990s witnessed the revival of the academic interest in the Phillips curve and "the Phillips curve has again been the subject of intensive debate (for example, the symposium proceedings in the Journal of Economic Perspectives" (Debelle and Vickery, 1998:384). Generally, empirical findings have shown the mixed results. Some researcher found the significant trade-off relationship between unemployment rate and inflation rates and other does not. Among research studies done in the 1990s, Alogoskoufis and Smith (1991) showed the empirical evidence to support the "Lucas critique" which denied the existence of trade-off relationship. By contrast, King and Watson (1994) tested the existence of the Phillips curve using the U.S. post-war macroeconomic data. Their findings provided empirical support to the existence of the trade-off relationship between unemployment and inflation in the USA over the researched period. Hansen and Pancs (2001) examined the existence of the Phillips curve in Lativa. They also found out that there is a significant correlation between the unemployment rate and the actual inflation rates. Furthermore, Islam et al. (2003) examined the hypothesis of Philips curve through US economic data from 1950 to 1999. They find out the weak long-run cointegrating relationship and long-run causality between unemployment and inflations. On the other hand, Hart (2003) tested the Phillips hypothesis by employing the hourly wage earning. He concluded that during inter-war period (1926-66) in Britain, the Phillips curve is "not supported by our data". Furuoka (2007) examined the long-run \& trade-off relationship and also causal relationship between the unemployment rate and the inflation rate in Malaysia during the period of 1975-2004).

A recent methodological innovation in assessing the Phillips curve has been the use of panel data analysis. Dinardo and Moore (1999) used panel data analysis to examine 9 member countries of the Organization for Economic Co-operation and Development (OECD). The researchers used the method of Ordinary Least Squares (OLS) and Generalized Least Squares (GLS). Their findings confirmed the existence of the "common" Phillips curve in these OECD countries. Turner and Seghezza (1999) also employed the panel data method and observed the Phillips curve in 21 OECD countries over the period from the early 1970s to 1997 . To analyze the pooled data, Turner and Seghezza used the method of Seemingly Un-related Estimation (SURE) rather than the OLS. The researchers concluded that the overall result provided a "strong support" for the existence of the "common" Phillips curve among the 21 chosen member countries of OECD. Arratibel et al. (2002) analyzed New Keynesian Phillips curve with forward-looking expectations by using panel data. They found that the unemployment rates have significant relationship with non-tradable inflation rates. By contrast, Masso and Staehr (2005) used the dynamic panel data method and failed to identify a significant relationship between unemployment rate and inflation rates.

Research on the Phillips Curve in Pakistan is very limited. Hasan (1990) supported the existence of a short-run Phillips Curve for Pakistan for the period 1972(Qtr.1) to 1981(Qtr.4). Malik and Tashfeen (2007) observed a negative relationship between inflation and one period lagged unemployment. Satti et al (2007) find that future inflationary expectations play significant role in inflation determination. A dynamic correlations between inflation and real marginal cost have been observed i.e., inflation co-moves positively with real marginal cost, both at leads and lags. 
Numerous studies on the Phillips curve are available on developed nations; there is huge scope for systematic empirical analysis that testifies the hypothesis in the context of a developing country. Considering important economic and political implications of Pakistan, the Phillips Curve hypothesis entails relationship between unemployment rate and inflation rate.

This paper analyzes the trade-off between inflation and unemployment in Pakistan using secondary data from 1975 to 2009. Following dimensions and factors of the Phillips curve hypothesis are focused.

* NAIRU: NAIRU is an acronym for Non-Accelerating Inflation Rate of Unemployment. The idea behind the natural rate hypothesis was put forward by Milton Friedman in 1968 and it refers to a level of unemployment, below which inflation rises. If $\mathbf{U}^{*}$ is the NAIRU and $\mathbf{U}$ is the actual unemployment rate, the theory says that:

- if $\mathrm{U}<\mathrm{U}^{*}$ for a few years, inflationary expectations rise, so that the inflation rate tends to accelerate;

- if $\mathrm{U}>\mathrm{U}^{*}$ for a few years, inflationary expectations fall, so that the inflation rate tends to fall (there is disinflation); and

- if $\mathrm{U}=\mathrm{U}^{*}$, the inflation rate tends to be stationary, unless exogenous shock is observed.

* Natural Rate of Unemployment: It is the unemployment, which occurs when the labour market is in the equilibrium (supply side of unemployment i.e., frictional and structural unemployment). If unemployment is reduced below the natural rate, there is an increased risk of inflation.

- Unemployment Gap: The difference between the non-accelerating inflation rate of unemployment (NAIRU) and the actual rate of unemployment is termed as unemployment gap. According to Pallis and Katsouli (2003), in the short-term, a trade-off do exists between price inflation and unemployment. If unemployment falls below the NAIRU, price inflation will rise until unemployment returns to the NAIRU, at that time price inflation will stabilize at a permanently higher level.

Co-integration technique is used for analysis. In this study a sophisticated econometric technique with additional tests of forecasting framework is used to examine the effect of changes in inflation on unemployment rate over a 10 years period.

\section{Brief Overview of Inflation and Unemployment Rate in Pakistan}

\subsection{Inflation Rate}

The rate of inflation is an important macroeconomic indicator by which the central banks around the world analyze and set their monetary policy. Pakistan is among those countries, which are still experiencing double digit inflation. There has been an increasing trend of inflation from 12 percent in 1975 to almost 22 percent in 2009. Inflation is documented in the range of 3 percent to 22 percent during the said period (see, Figure 1).

\subsection{Unemployment Rate}

In 1970 s, average unemployment rate was 3.43 percents. It increased by only 0.1 percent in the year 1980 s (3.44\%). Afterward, average unemployment rate increased sharply in the year 1990s and 2000s, where average unemployment rate was reported almost 5.56 and 6.97 percent respectively (see Figure 2).

\subsection{Changes in Inflation (IFR) and Unemployment Rate (UN) in Pakistan}

The relationship between unemployment and inflation rate in Pakistan is an interesting example. There have been greater fluctuations in inflation and unemployment rate during the years 1975-2009. Hence, there has been found an inverse relationship between unemployment rate and inflation rate.

$\triangle I F R=\mathbf{C}+\triangle I F R(-1)+U N+u$

$\mathrm{C}=3.328(0.046)^{*} ; \quad \Delta I F R(-1)=0.638(0.000) * U N=-0.361(0.050)^{*}$

Adjusted R-square $=0.41 ; \mathrm{D} . \mathrm{W}=1.903 ;$ F-statistics $=9.672(0.000)^{*}$

Note: * represent $0.05 \%$ significance level.

\subsection{Unemployment Rate (UN) and Unemployment Gap (UNGAP) in Pakistan}

Unemployment Gap is the difference between the non-accelerating inflation rate of unemployment (NAIRU) and the actual unemployment rate (UN). NAIRU is estimated from 1975-2009 and observed as 7.8 percent, while average unemployment rate was 4.9 percent which is less than the NAIRU. It means that inflationary expectations have been raised between these years, so high inflationary tends is observed. Unemployment gap is observed up to 2.81 percent between the said periods. Unemployment and unemployment gap for the period of 1975-2009 are mentioned in Figure 3.

\section{Data Sources and Methodological Framework}

The study uses annual observations for the period of 1975-2009. The data is obtained from Economic Survey of Pakistan (2008-09), International Financial Statistics (2007-08), and World Bank Development Indicators data sets (WDI-2009). This paper reviews; the impact of the unemployment on inflation within the context of Phillips Curve, which is examined in the following manner: 
- By examining whether a time series unit root test is applied; an Augmented Dickey-Fuller (ADF) unit root test has been used.

- By finding the long-run relationship among the variable, cointegration test has been applied.

- When the variables are found cointegrated, a Granger causality test based on Vector Error Correction Method (VECM) has been applied to determine the short and long-run causality.

- By describing the reaction of endogenous variable i.e., unemployment at the time of impulse / shock and over subsequent points in time.

\subsection{Theoretical Methodology}

The simple Phillips Curve could be estimated by using following equations. If we let $w_{t}$ be the wage rate in time $t$, we may represent the proportional or percentage change in the wage rate as:

$$
w_{t}=\frac{w_{t}-w_{t-1}}{w_{t-1}}
$$

If we assume that $w_{t}$ is proportional to the excess demand for labour $d_{t}$, we may write:

$$
w_{t}=\gamma d_{t}
$$

Where $\gamma$ is constant. Since the unemployment rate $u_{t}$ is inversely related to the excess demand for labor, we could write this using our reciprocal function as:

$$
d_{t}=a+c \frac{1}{u_{t}}
$$

Given equation (3), we may then specify $w_{t}$ as:

$$
w_{t}=\gamma a+\gamma c \frac{1}{u_{t}}
$$

Where $w_{t}$ is linearly related to the non-linear reciprocal variable $u_{t}$. An appropriate linear statistical model may then be:

$$
y_{t}=\beta_{1}+\beta_{2} x_{t}+e_{t}
$$

Where $y_{t}=w_{t}=\left(w_{t}-w_{t-1}\right) / w_{t-1}$

$x_{t}=\frac{1}{u_{t}}$ and $e_{t}$ is a normal random equation error.

Simply, we can write equations with the aid of notation we are using for the variables in our paper, incorporating natural rate of unemployment into the model, the "standard" Phillips Curve could be expressed:

$$
I F R_{t}=\alpha(L) I F R_{t-1}+\beta(L)\left(U R_{t}-N A I R U_{t}\right)+\varepsilon_{t}
$$

Where, $\alpha(L)$ and $\beta(L)$ are polynomials in the lag operation, NAIRU is natural rate of Unemployment in Pakistan in the year $t$, and. According to Debelle and Vockery (1998), "most of the existing theoretical and empirical literatures" have been based on the equation 2 . The equation could be modified as:

$$
I F R_{t}=\alpha(L) I F R_{t-1}+\beta(L)\left(U N G A P_{t}\right)+\varepsilon_{t}
$$

Where UNGAP is the "unemployment gap" (i.e. the actual unemployment rate minus natural rate of unemployment rate). To support the Phillips curve, we would require negative and significant coefficients for the unemployment gap. The empirical analysis will be based on the equation 3 .

\subsection{Econometric Methodology}

The concept of Cointegration was first introduced by Granger (1981) and elaborated further by Engle \& Granger (1987), Phillips \& Ouliaris (1990) and Johansen (1991). Engle \& Granger Cointegration test requires that

- Time-series, say $Y_{t}$ and $X_{t}$, are non-stationary in levels but stationary in first differences i.e., $Y_{t} \sim I(1)$ and $X_{t} \sim I(1)$. 
- There exists a linear combination between these two series that is stationary at levels i.e., $v_{i t}\left(=Y_{t}-\hat{\alpha}-\hat{\beta} X_{t}\right) \sim I(0)$.

Thus, the first step for Cointegration is to test whether each of these series are stationary or not. If they both are stationary say at first difference i.e. they are $I(1)$, then we proceed to the second step to verify the long run relationship between them.

Augmented Dickey Fuller (ADF) test is usually applied to test stationarity. It tests the null hypothesis that a series $\left(Y_{t}\right)$ is non-stationary by calculating a t-statistics for $\beta=0$ in the following equation:

$\Delta Y_{t}=\alpha+\beta Y_{t-1}+\gamma_{t}+\sum_{k=2}^{n} \delta_{k} \Delta Y_{t-k}+\varepsilon_{t}$

Where $\mathrm{k}=2,3, \ldots, \mathrm{n}$. While $\alpha, \beta, \gamma$ and $\delta$ are the parameters to be estimated and $\varepsilon_{t}$ is white noise error term.

If the value of the ADF statistic is less than the critical value at the conventional significance level (usually the $5 \%$ significance level is desirable) than the series $\left(Y_{t}\right)$ is said to be stationary and vice versa. If $Y_{t}$ is found to be non-stationary then it should be determined whether $Y_{t}$ is stationary at first differences $\Delta Y_{t} \sim I(0)$ by repeating the above procedure. If the first difference of the series is stationary than the series $\left(Y_{t}\right)$ are integrated of order one i.e. $Y_{t} \sim \mathrm{I}(1)$.

If time series are $I(1)$, than regressions is applied in their first difference. However, by taking first difference, we lose the long-run relationship that is stored in the data. This implies that one needs to use variables in levels as well. Advantage of the Error Correction Model (ECM) is that it incorporates variables both in their levels and first difference. By doing this, ECM captures the short-run disequilibrium situations as well as the long-run equilibrium adjustments between variables. ECM term having negative sign and value between " 0 to 1 " indicates convergence of model towards long-run equilibrium and shows how much percentage adjustment takes place every year.

Impulse response functions trace the effects of a shock to one endogenous variable on to the other variables in the VAR; variance decomposition separates the variation in an endogenous variable into the component shocks to the VAR. Thus, the variance decomposition provides information about the relative importance of each random innovation in affecting the variables in the VAR.

This study runs the Granger-causality test based on the following the VECM:

$$
\Delta I F R_{t}=\beta_{1 i}+\sum_{i=1}^{n} \beta_{2 i} \Delta(U N G A P)_{t-i}+\sum_{i=1}^{n} \beta_{3 i} \Delta(I F R)_{t-i}+\beta_{4}(E C T)_{t-1}+\varepsilon_{t}
$$

This paper uses the Granger-causality test based on the VECM. There are two advantages to using this method rather than the standard Granger causality test. First of all, the Wald test of the independent variables indicates the short-run causal effect. Secondly, significant and negative error correction term $(E C T)_{t-1}$ indicates the long-run causal effects.

\section{Empirical Results}

NAIRU is estimated for 1975-87, 1988-98 and 1999-2009 with the values 6.01, 3.21 and 9.01 respectively. NAIRU for overall period i.e., 1975-2009 is estimated as 7.80, which is greater than average unemployment rate of 4.99 percent. Results reveal that inflation was less for the period i.e., 1975-1987 and 1988-1998. While, there was an increasing trend of inflation for the period 1999-2009. Overall incidence of inflation for 1975-2009 has shown an increasing trend. The cumulative effect of this rising expected inflation rate is positive, with unemployment gap is (-) 2.81 percent over a 35 years period. In the short-term, a trade-off exists such that if unemployment rate falls below the NAIRU, inflation will rise until unemployment returns to the NAIRU. At that time inflation will stabilize at a permanently higher level (see, Table 1).

The preliminary step in this analysis is to establish the degree of integration of each variable. So a test for the existence of a unit roots in the level and the first difference of each variable in our sample using the Augmented Dickey Fuller (ADF). The results in Table 2 reveal that both variables are non-stationary in their level data. However, stationarity is found in the first differencing level of the variables i.e., Inflation rate (IFR) and unemployment gap (UNGAP).

In the second stage, the Johansen cointegration test was used to test the long-run movement of the variables. Engle and Granger (1987) have pointed out that only variables with the same order of integration could be tested for cointegration. Both variables were examined for cointegration at their first difference I(1). Akaike Information Criterion (AIC) was used to determine optimal lag length selection, while maximum lag length is set up to level three. Table 3 shows that optimal lag length for the Johansen cointegration test is one (1), which minimizes the AIC. 
Results of the cointegration tests are reported in Table 4 and Table 5 respectively. Starting with the null hypothesis of no cointegration among the variables, the trace statistics of 19.23 exceeds the $95 \%$ critical value of the $\lambda$ trace statistic (critical value is 15.49). The null hypothesis is valid up to $5 \%$ level of confidence. It is concluded that there is one cointegration relationship involving variables i.e., IFR and UNGAP.

In Table 5, $\lambda \max$ statistic rejects the null hypothesis of no cointegration vector against the alternative as the calculated value $\lambda$ max are 16.49 , which is exceeding the $95 \% \mathrm{t}$ critical value (14.26). Thus, on the basis of $\lambda$ max statistic there is one co-integration vectors. The presence of cointegration vector shows that there exists a long-run relationship among the variables.

The Granger-causality method based on the VECM was employed to examine the long-run and short-run casual relationships between the two variables. Firstly, the Akaike Information Criterion was used to determine the optimal length for the causality test. As Table 6 shows, optimal lag length for causality test is two (2) which minimizes the AIC.

The dynamic short-run causality (by using Wald test) and the long-run causality by error correction term $\left(E C T_{t-1}\right)$ among the relevant variables are shown in Table 7. The causality effect can be obtained by restricting the coefficient of the variables with its lags equal to zero. If the null hypothesis of no causality is rejected, then we conclude that a variable Granger-caused other variable. To recapitulate the findings of the short-run causality test, we conclude that the hypothesis of inflation-unemployment is legitimate in the Pakistan's economy, as there appeared to be a negative relationship. In other words, Pakistan's unemployment rate does "Granger cause" inflation in the short-run.

In the long-run causality test, the error correction term $\left(E C T_{t-1}\right)$ is statistically significant and negative. This means that there is a long-run Granger causality between the inflation rate and unemployment rate. The error-correction term is significant with an adjustment coefficient of -0.259 , indicating that inflation rate (IFR) adjusts to its long-run equilibrium level with $25.9 \%$ of the adjustment taking place within the first year. The sign of the ECT coefficient also specifies that changes in the inflation rate adjust in an opposite direction to the previous period's deviation from equilibrium. In other words, the long-run Granger causality does confirm the existence of the long-run equilibrium relationship between unemployment rate and inflation rate in Pakistan as indicated in the Johansen cointegration test.

Figures 4-7 plot the impulse-response functions of inflation and unemployment to the permanent and transitory shock. The impulse-response functions show due to consequence of transitory and permanent shocks, there had been an increase in unemployment, which has ultimately reduced the inflation rate. A short-run and long-run tradeoff between the two variables is observed. This adverse effect on unemployment of a negative demand shock is very persistent. In fact, the two variables move in the opposite direction at different frequencies. Indeed, the selected cointegrating vector implies that, there is a long-run relationship between the variables, inflation and unemployment. Hence, the analysis enables the conclusion that these supply shocks drive the rare movement of inflation and unemployment in the long run.

Figure 8-11 plot the variance decomposition function of inflation and unemployment. The variance decomposition analysis indicates that inflation rate is the exogenous variable. A high proportion of its shock is explained by the own innovations compared to the unemployment. At the end of 10 years, the forecast error variance for inflation explained by their own innovations is $317.8 \%$, while the forecast error variance for unemployment explained by their own innovation is $87.2 \%$.

At the end, empirical findings of the present study show that there is a long-run relationship and also causality between Pakistan's unemployment rate and inflation rate. These findings provide an strong empirical support for the existence of the Phillips curve, in the context of a developing country like Pakistan.

\section{Summary and Conclusion}

Inflation is a universal phenomenon. Every one is affected by inflation. Being an economist, it is a social responsibility to explore the reality mentioned by Phillips Curve i.e., increased inflation results into increased job opportunities which ultimately lead to economic growth in the country. This study provides strong empirical existence of Phillips Curve in Pakistan, both in the long- and short-runs. On the basis of this study, one can forecast the future trend for the next ten years will be in favor of Phillips curve. Policy makers can get guidance from this paper for making future policy decisions for Pakistan. This research can be replicated for other developing countries especially SAARC countries, such as Bangladesh, Bhutan, India, Maldives, Nepal, and Srilanka. By assessing the existence of the Phillips curve in SAARC economies can have more insight.

\section{References}

Akaike, H. (1974). A New Look at the Statistical Model Identification. IEEE Transaction on Automatic Control, Vol.19, pp.716-723.

Alogoskoufis, G. and Smith, R. (1991). The Phillips Curve: The Persistence of Inflation and the Lucas Critique: Evidence from Exchange-Rate Regime. American Economic Review, 81, pp.1254-1275. 
Arratibel, O., Rodriguez-Palenzuela, D. and Thimann, C. (2002). Inflation Dynamics and Dual Inflation in Accession Countries: A New Keynesian Prospective. ECB Working Paper, No. 132.

Debelle, G. and Vickery J. (1998). Is the Phillips Curve: Some Evidence and Implications for Australia. The Economic Record, 74, pp.384-398.

Dickey, D. and Fuller, W. (1979). Distribution of the Estimators for Autoregressive Time Series with a Unit Root. Journal of the American Statistical Association, Vol. 74, No.366, pp. 427-431.

Dickey, D. and Fuller, W. (1981). Likelihood Ratio Tests for Autoregressive Time Series with a Unit Root. Econometrica, Vol.49, No. 4, pp.057-1072.

DiNardo, J. and Moore, M.(1999). The Phillips Curve is Back? Using Panel Data to Analyze the Relationship Between Unemployment and Inflation in an Open Economy. NBER Working Paper 7328, pp.1-27.

Economic Survey. (2008-09). Economic Survey of Pakistan. Government of Pakistan (2008), Finance Division, Economic, Advisor's Wing, Islamabad, Pakistan.

Economic Survey of Pakistan, various issues. Government of Pakistan (2008), Finance Division, Economic, Advisor's Wing, Islamabad, Pakistan.

Engle R. and Granger, C. (1987). "Co-integration and Error Correction: Representation, Estimation and Testing", Econometrica, Vol.55, No. 2, pp.251-276.

Furuoka, F. (2007). Does the "Phillips Curve Really Exist? New Empirical Evidence from Malaysia. Economics Bulletin, Vol. 5, No. 16 pp. 1-14

Friedman, M. (1968). The Role of Monetary Policy. American Economic Review, 58,pp. 1-17

Gordon, R.J. (1971). Price in 1970: The Horizontal Phillips Curve. Brookings Papers on Economic Activities, 3, pp.449-458.

Granger, C. W. J. (1981). Some Properties of Time Series Data and Their Use in Econometric Model Specification, Journal of Econometrica, 16: 121-30

Hansen, M and Pancs, R. (2001). The Latvian Labour Market Transition: the Beveridge and Phillips Curve as Indicators of Normalization, Riga: Euro Faculty.

Hart, R. A. (2003). Overtime Working, the Phillips Curve and the Wage Curve. The Manchester School, .71(2), pp.97-112.

Hasan, A, M. (1990). Phillips Curve Analysis: Some Experiences from Pakistan's Economy. Journal of Economic Studies, Volume 17, Issue $1, \quad$ available http://demo1.emeraldinsight.com/Insight/viewContentItem.do;jsessionid=4FC6611A41E83D46E2A6053340A01EA E? contentType $=$ Article\&hdAction $=$ lnkpdf\&contentId $=845881$ \&history $=$ true

IFS. (2008). International Financial Statistics 2008, International Monetary Fund, Washington, available online at http://www.imfstatistics.org/imf accessed on Mach 15, 2010.

Johansen, S. (1991). "Estimation and Hypothesis Testing of Cointegrated Vectors in Gaussian VAR Models", Econometrica, 59(6), pp.1551-1580.

King, R.G. and Watson, M.W. (1994). "The Post-War U.S. Phillips Curve: A Revisionist Econometric History", Carnegie-Rochester Conference Series on Public Policy, 41, pp.157-219.

Islam, F., Hassan, K., Mustafa, M. and Rahman, M. (2003). The Empirics of U.S. Phillips Curve: A Revisit, American Business Review, 20(1), pp.107-112.

Lucas, R.E. (1976). Econometric Policy Evaluation: A Critique. Carnegie-Rochester Conference Series on Public Policy, 1, pp.19-46.

MacKinnon, J.G., Haug, A.A., and Michelis, L. (1999). Numerical distribution functions of likelihood ratio tests for cointegration. Journal of Applied Econometrics, 14, 563-577.

Malik, W. S., A. H. But. and M. A. Tashfeen. (2007). Phillips Curve Relation over the Business Cycle: Evidence from Pakistan. Kashmir Economic Review, XVI, No. 1, pp. 1-16.

Masso, J. and Staehr, K. (2005). Inflation Dynamics and Nominal Adjustment in Baltic States. Research in International Business and Finance, 19, pp.281-303.

Phelps, E. (1967). Phillips Curve, Expectation of Inflation, and Optimal Inflation over Time. Economica, 34, pp.254-281.

Phillips, A.W.(1958). The Relationship between Unemployment and the Rate of Change of Money Wage Rates in the United Kingdom. Economica, 25, pp.258-299.

Philips, P. C. B. and S. Ouliaris. (1990). Asymptotic Properties of Residual Based Tests for Cointegration, Econometrica, 58: 165-93. 
Samuelson, P.A. and Solow, R.M. (1960). Analytical Aspect of Anti-inflation Policy. American Economic Review, 50, pp.177-194.

Satti, A. H; Wasim, S. M and Ghulam, S. (2007). New Keynesian Philips Curve for Pakistan. The Pakistan development Review, 46: 4, Part 11 (Winter 2007), pp. 395-404.

Solow, R.M. (1970). Discussion of RJ Gordon's Recent Acceleration of Inflation and its Lessons for the Future. Brookings Papers on Economic Activities, 1, pp.42-46.

Turner, D. and Seghezza, E. (1999). Testing for a common OECD Phillips curve. OECD Economic Development Working Paper, NO. 219.

WDI. (2009). World Development Indicator, the World Bank Group, Online available at: http://go.worldbank.org/U0FSM7AQ40 accessed on March 20, 2010.

Table 1. NAIRU Estimates

\begin{tabular}{|c|c|c|c|c|c|}
\hline Sample Period & NAIRU & Average UE & $\begin{array}{c}\text { Expected } \\
\text { Inflation }\end{array}$ & UEGAP & $\mathrm{R}^{2}$ \\
\hline $1975-1987$ & 6.01 & 8.45 & Falls & 2.44 & 0.48 \\
$1988-1998$ & 3.21 & 10.04 & Falls & 6.83 & 0.42 \\
$1999-2009$ & 9.01 & 6.98 & Rises & -2.03 & 0.33 \\
$1975-2009$ & 7.80 & 4.99 & Rises & -2.81 & 0.41 \\
\hline
\end{tabular}

Source: Authors calculation. UE = Unemployment Rate; UEGAP = Unemployment Gap

Table 2. ADF Unit Root Test

\begin{tabular}{|c|c|c|c|c|}
\hline & \multicolumn{2}{|c|}{ Levels } & \multicolumn{2}{c|}{ First Difference } \\
\hline & Constant & Constant with trend & Constant & Constant with trend \\
\hline IFR & $-2.518(4)$ & $-2.190(0)$ & $-6.429^{*}(0)$ & $-6.580^{*}(0)$ \\
\hline UNGAP & $-1.484(0)$ & $-1.875(0)$ & $-5.597 *(0)$ & $-5.543^{*}(0)$ \\
\hline
\end{tabular}

Note: Figures in parenthesis indicate number of lag structures. * indicates significance at $1 \%$ level.

Table 3. Optimal Lag Length Selection for the Cointegration Test (Maximum Lag length $=3$ )

\begin{tabular}{|c|c|}
\hline Lag Length & AIC \\
\hline 0 & 9.206 \\
1 & $7.358^{*}$ \\
2 & 7.455 \\
3 & 7.604 \\
\hline
\end{tabular}

Note: AIC denotes the Akaike Information Criterion. * indicates optimal lag length selected by AIC

Table 4. The Johansen Cointegration Test $\quad$ (Trace Eigenvalue Statistic)

\begin{tabular}{|c|c|c|c|c|}
\hline Eigenvalue & Trace Statistic & 5 percent critical value & Prob.** & $\begin{array}{c}\text { Number of cointegrating } \\
\text { equations }\end{array}$ \\
\hline 0.402731 & 19.23154 & 15.49471 & 0.0130 & None* $^{*}$ \\
\hline 0.082036 & 2.739118 & 3.841466 & 0.0979 & At most 1 \\
\hline
\end{tabular}

Note: The result corresponds to VAR's with one lag. * denotes rejection of the hypothesis at the 0.05 level. **MacKinnon-Haug-Michelis (1999) p-values.

Table 5. The Johansen Cointegration Test (Maximum Eigenvalue Statistic)

\begin{tabular}{|c|c|c|c|c|}
\hline Eigenvalue & Max-Eigen Statistic & 5 percent critical value & prob.** & Number of cointegrating equations \\
\hline 0.402731 & 16.49242 & 14.26460 & 0.0219 & None* $^{*}$ \\
\hline 0.082036 & 2.739118 & 3.841466 & 0.0979 & At most 1 \\
\hline
\end{tabular}

Note: The result corresponds to VAR's with one lag. * denotes rejection of the hypothesis at the 0.05 level. **MacKinnon-Haug-Michelis (1999) p-values.

Table 6. Optimal Lag Length Selection for Causality Test $\quad$ (Maximum Lag length $=3$ )

\begin{tabular}{|c|c|}
\hline Lag Length & AIC \\
\hline 0 & 8.948 \\
1 & 7.583 \\
2 & $7.474^{*}$ \\
3 & 7.743 \\
\hline
\end{tabular}

Note: AIC denotes the Akaike Information Criterion. * indicates optimal lag length selected by AIC 
Table 7. Granger-Causality Test Based on VECM

(Dependent Variable: D (IFR))

\begin{tabular}{|c|c|c|}
\hline Variable & Degree of Freedom & Wald Test Statistics \\
\hline D(UEGAP) & 2 & $3.961 *$ \\
\hline \multicolumn{2}{|c|}{} & Value \\
\hline Adjustment Coefficient & -0.259 & t-statistic \\
\hline$(\text { ECT })_{t-1}$ & $-2.218 * *$ \\
\hline
\end{tabular}

Note: To test for causality when variables are co-integrated, the following Granger causality test based on the VECM could be used: $D(I F R)_{t}=\beta_{1}+\sum_{i=1}^{n} \beta_{2 i} D\left(U E G A P_{t-1}\right)+\sum_{i=1}^{n} \beta_{3 i} D\left(I F R_{t-1}\right)+\beta_{4 i}(E C T)_{t-1}+\varepsilon_{t}$

1) Short-run causality: the joint significance of the coefficients is determined by the Wald Test

2) Long-run causality: the level of significance for error correction term (ECTt-1) is determined by the t-statistics.
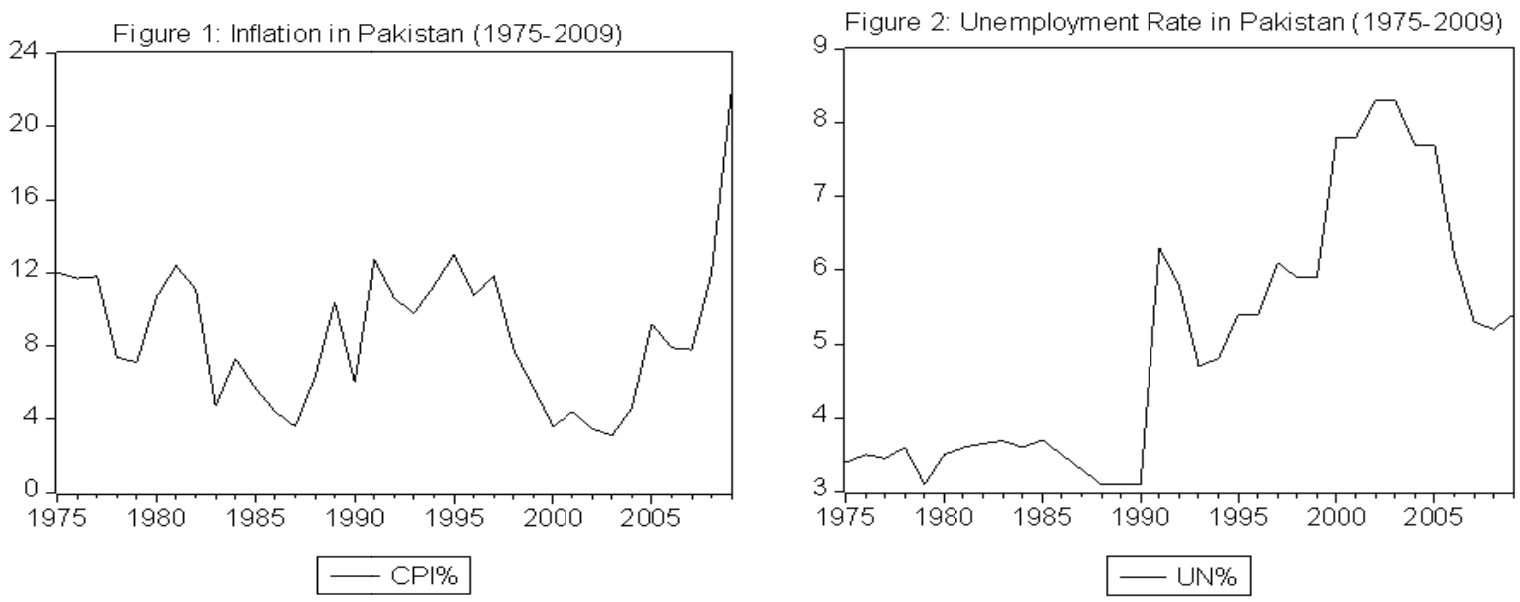

Figure 3: Unemployment Rate, Unemployment Gap and NAIRU in Pakistan (1975-2009)

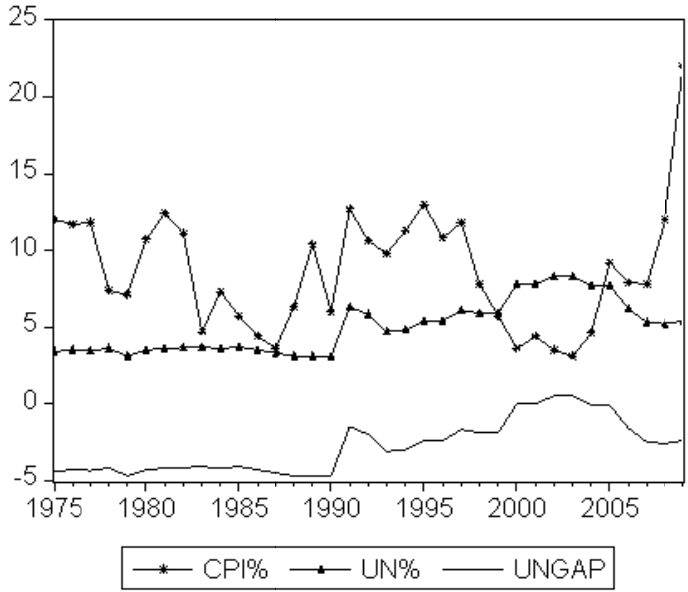



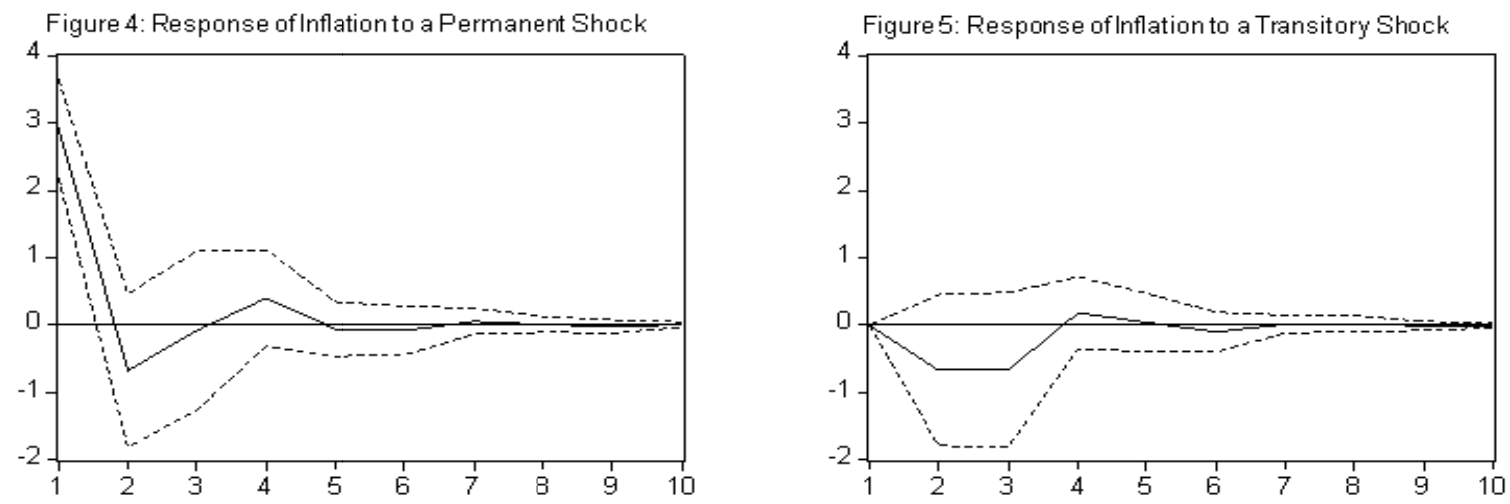

Figure 6: Response of Unemployment to a Permanent Shock

Figure 7: Response of Unemployment to a Transit ory Shock
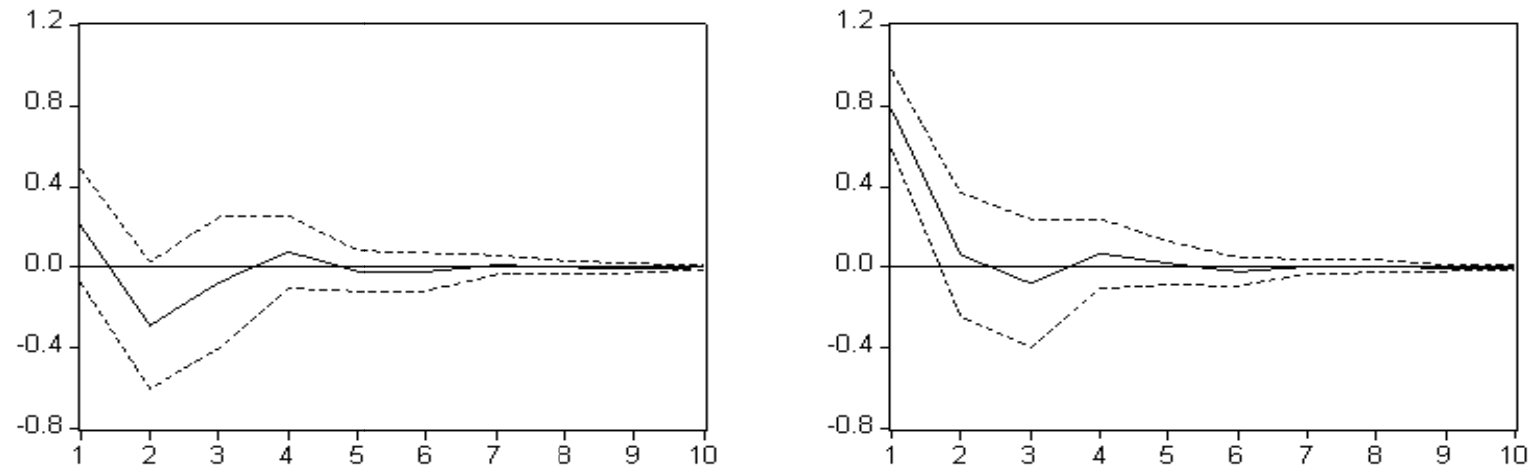

Figure 4-7.Impulse Response Shocks
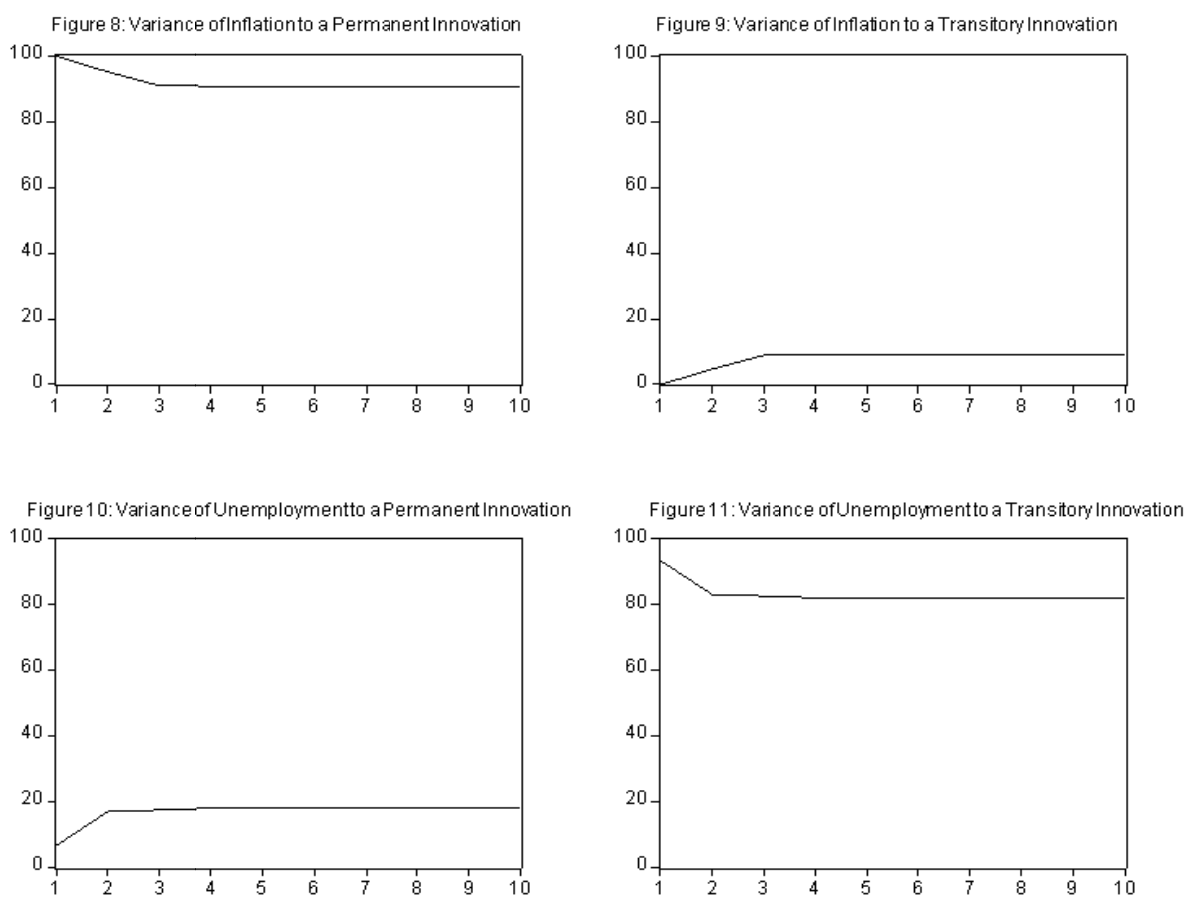

Figure 8-11: Variance Decomposition Analysis

Note: $* *$ indicates significance at $5 \%$ level. $*$ indicates significance at $1 \%$ level 